\title{
NMDA Receptor Activation Inhibits $\alpha$-Secretase and Promotes Neuronal Amyloid- $\beta$ Production
}

\author{
Sylvain Lesné, ${ }^{1,3}$ Carine Ali, ${ }^{1,2}$ Cecília Gabriel, ${ }^{1}$ Nicole Croci, ${ }^{5}$ Eric T. MacKenzie, ${ }^{1}$ Charles G. Glabe, ${ }^{4}$ Michel Plotkine, ${ }^{5}$ \\ Catherine Marchand-Verrecchia, ${ }^{5}$ Denis Vivien, ${ }^{1,2}$ and Alain Buisson ${ }^{1}$ \\ ${ }^{1}$ Unité Mixte de Recherche, Centre National de la Recherche Scientifique 6185, Centre Cyceron, and ${ }^{2}$ Equipe Institut National de la Santé et de la Recherche \\ Médicale Avenir tPA in the Working Brain, Université de Caen, 14074 Caen Cedex, France, ${ }^{3}$ Department of Neurology, University of Minnesota, \\ Minneapolis, Minnesota 55455, ${ }^{4}$ Department of Molecular Biology and Biochemistry, University of California, Irvine, Irvine, California 92697, \\ and ${ }^{5}$ Faculté des Sciences Pharmaceutiques et Biologiques, Université Paris 5, Laboratoire de Pharmacologie-EA2510, 75006 Paris, France
}

Acute brain injuries have been identified as a risk factor for developing Alzheimer's disease (AD). Because glutamate plays a pivotal role in these pathologies, we studied the influence of glutamate receptor activation on amyloid- $\beta$ (A $\beta)$ production in primary cultures of cortical neurons. We found that sublethal NMDA receptor activation increased the production and secretion of $A \beta$. This effect was preceded by an increased expression of neuronal Kunitz protease inhibitory domain (KPI) containing amyloid- $\beta$ precursor protein (KPI-APP) followed by a shift from $\alpha$-secretase to $\beta$-secretase-mediated APP processing. This shift is a result of the inhibition of the $\alpha$-secretase candidate tumor necrosis factor- $\alpha$ converting enzyme (TACE) when associated with neuronal KPI-APPs. This KPI-APP/ TACE interaction was also present in AD brains. Thus, our findings reveal a cellular mechanism linking NMDA receptor activation to neuronal $\mathrm{A} \beta$ secretion. These results suggest that even mild deregulation of the glutamatergic neurotransmission may increase $\mathrm{A} \beta$ production and represent a causal risk factor for developing AD.

Key words: amyloid; APP; secretase; glutamate receptors; calmodulin; neurons

\section{Introduction}

Traumatic brain injuries (TBIs) have been identified as an environmental risk factor for Alzheimer's disease (AD) (Heyman et al., 1984; Mortimer et al., 1991; Guo et al., 2000; Plassman et al., 2000; Uryu et al., 2002; Fleminger et al., 2003), an age-related neurodegenerative disease associated with progressive decline of cognitive function. One of the pathological hallmarks of $\mathrm{AD}$ is the abnormal accumulation of amyloid- $\beta$ (A $\beta$ ) (a 40-42 amino acid-long peptide) within vascular walls and in the cerebral parenchyma (Glenner and Wong, 1984; Masters et al., 1985). Indeed, among patients suffering from head injury, $30 \%$ display $\mathrm{A} \beta$ deposition within $7 \mathrm{~d}$ (Roberts et al., 1991; Roses and Saunders, 1995). These findings suggest that acute brain injuries, such as TBI, may trigger deposition of $A \beta$ (Smith et al., 1998, 2003). In addition, a recent study pointed out the transient upregulation of $\beta$-secretase BACE-1 [ $\beta$-site amyloid precursor protein (APP) cleaving enzyme] expression $24-72 \mathrm{~h}$ after TBI, accompanied by an elevation of its activity detected $48 \mathrm{~h}$ after onset (Blasko et al.,

Received March 3, 2005; revised July 8, 2005; accepted Aug. 29, 2005

This work was supported by the Centre National de la Recherche Scientifique, the University of Caen, and the Institut Paul Hamel. S. L. was supported by a doctoral fellowship from the Conseil Régional de Basse Normandie. We thank Dennis Selkoe, Luc Buée, André Delacourte, Nicolas Sergeant, Frédéric Checler, Peter Seubert, and Nikolaos Robakis for providing the R1736, R1742, R600, APPCter-C17, FCA3542, 192wt, and R7 antisera. Also, we thank Patrick Cleary and Hae-Sun Park for their technical help and Karen H. Ashe for her support.

Correspondence should be addressed to Dr. Alain Buisson, Unité Mixte de Recherche, Centre National de la Recherche Scientifique 6185, Centre Cyceron, Boulevard H. Becquerel, BP5229, 14074 Caen Cedex, France. E-mail: buisson@cyceron.fr.

D0I:10.1523/JNEUROSCI.0849-05.2005

Copyright $\odot 2005$ Society for Neuroscience $\quad$ 0270-6474/05/259367-11\$15.00/0
2004). Although the overall understanding of the conditions that govern $\mathrm{A} \beta$ accumulation into the brain parenchyma has greatly improved, the molecular mechanism linking acute brain injury to an increased $\mathrm{A} \beta$ production remains to be established (Roberts et al., 1994; Saido et al., 1994; Popa-Wagner et al., 1998).

It is now an accepted fact that, in acute brain injuries, glutamate (the predominant excitatory neurotransmitter in the mammalian nervous system) plays a pivotal role (Choi, 1988) in such a way that acute neuronal injury is thought to result from an excessive release of excitatory amino acids and the subsequent overactivation of their postsynaptic receptors. Accordingly, neuronal culture models of glutamate toxicity have been extensively used to investigate the mechanisms of neuronal injury associated with these pathologies. The first event in the glutamate induced neuronal injury is mediated by the activation of ion channellinked glutamate receptors, especially NMDA receptors (NMDARs), probably because of their high-calcium $\left(\mathrm{Ca}^{2+}\right)$ permeability (Choi, 1995). The subsequent activation of cytoplasmic calcium-dependent enzymes has been proposed to mediate the final step of this deleterious pathway leading to an "excitotoxic" necrosis. However, despite this intuitive link between acute brain injuries and necrosis, a growing body of evidence indicates that TBI and ischemic insults also trigger neuronal apoptosis (Bramlett and Dietrich, 2004).

The genesis of $A \beta$ peptide is attributable to the processing of a transmembrane glycoprotein, the APP. APP is encoded by a single gene of 18 exons on chromosome 21. Exons 7, 8, and 15 of the APP gene can be alternatively spliced to produce multiple iso- 
forms. In the brain, the major isoform transcripts result from the splicing of exons 7 and 8, which gives rise to $\mathrm{APP}_{695}$, $\mathrm{APP}_{751}$, and $\mathrm{APP}_{770}$ (Selkoe, 2001). $\mathrm{APP}_{770}$ and $\mathrm{APP}_{751}$ both contain a serine protease inhibitory domain encoded by exon 7 called Kunitz protease inhibitory domain (KPI). KPI-APPs are mainly expressed in the brain by astrocytes and microglia, whereas the KPI-deficient APP, $\mathrm{APP}_{695}$, is abundant in neurons (LeBlanc et al., 1991). APP is processed in a twostep cleavage by several proteases, named $\alpha-, \beta-$, and $\gamma$-secretases (Selkoe, 2001). The amyloidogenic pathway involves a $\beta$-secretase cleavage of the $\mathrm{A} \beta \mathrm{N}$ terminus and generates a soluble fragment named sAPP $\beta$. The C-terminal membranebound remaining fragment undergoes $\gamma$-secretase processing, leading to $\mathrm{A} \beta_{40}$ or $\mathrm{A} \beta_{42}$ formation. An alternative pathway involves the cleavage of APP by $\alpha$ - and $\gamma$-secretases that generate a soluble APP derivative, $\operatorname{sAPP} \alpha$, containing the first 17 residues of $\mathrm{A} \beta$ and a $3 \mathrm{kDa}$ peptide (p3) similar to the 17-40/42 region of $A \beta$.

By studying the relationship between acute brain injuries and $\mathrm{AD}$, we may learn more about the deleterious pathway leading to $\mathrm{AD}$. In the present study, we investigated how acute brain injury may act as a risk factor for AD by studying the link between excitotoxicity, apoptosis, and $\mathrm{A} \beta$ production.

\section{Materials and Methods}

PCR and reverse transcriptase system kits were purchased from Promega (Charbonnières, France). DMEM, poly-D-lysine, cytosine $\beta$-Darabinoside (AraC), horse and fetal calf sera, proteinase $\mathrm{K}$, sodium citrate, staurosporine (STP), calcimycin (A23187), 1,2-bis(2aminophenoxy)ethane- $N, N, N^{\prime}, N^{\prime}$-tetraacetic acid tetrakis(acetoxy-methyl) ester (BAPTAAM), 1,4-dihydro-2,6-dimethyl-4-(3-nitrophenyl)-3,5-pyridinedicarboxylic acid 2-methoxyethyl 1-methylethyl ester (nimodipine), J8, $\mathrm{KN}-93$, anti-microtubule associated protein2 (MAP-2), and anti-actin antibodies were obtained from Sigma (L'Isle d'Abeau, France). NMDA, AMPA, 6-cyano-7-nitroquinoxaline-2,3-dione (CNQX), kainate, and (+)5-methyl-10,11-dihydro$5 H$-dibenzo(a,b)cyclohepten-5,10-imine maleate (MK-801) were from obtained from Tocris Cookson (Bristol, UK). Laminin was obtained from Invitrogen (Cergy Pontoise, France).

Semiquantitative reverse transcription-PCR. Total RNAs from primary cultures of cortical neurons were isolated by using RNAeasy extraction columns (Qiagen, Courtaboeuf, France). Total RNAs from brain tissue samples were prepared by a phenol/chloroform extraction method using the RNAxel extraction kit (Eurobio, Paris, France). One microgram of total RNA was transcribed into cDNA by using poly-dT oligonucleotides. For semiquantitative experiments, each PCR amplification was tested to reach half of the saturation curve, and an aliquot of cDNA libraries was amplified by PCR with specific oligonucleotides for $\beta$-actin ( $539 \mathrm{bp}$ PCR product). Similarly, an aliquot of the same cDNA libraries was amplified

$\boldsymbol{e}$

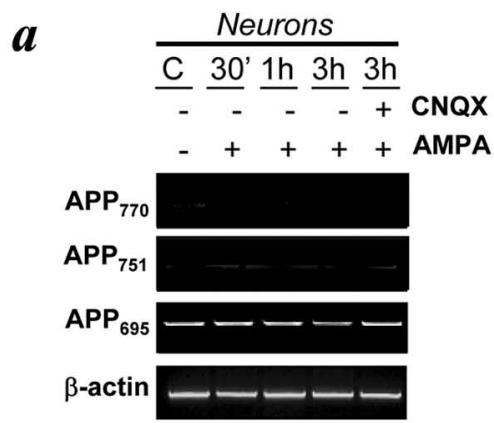

$b$
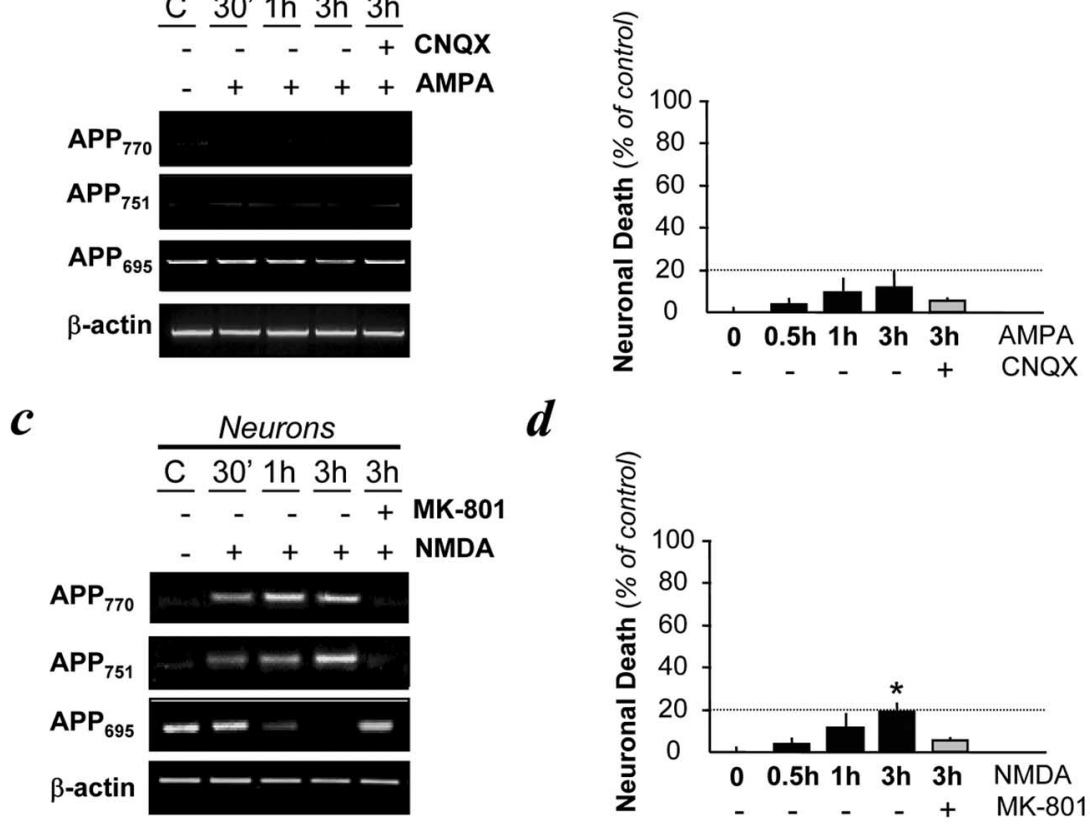

Figure 1. Expression of KPI-APP mRNAs in cultured cortical neurons subjected to NMDA-induced excitotoxicity. $\boldsymbol{a}$, Transcriptional expression of APP isoforms in neurons exposed to AMPA $(50 \mu \mathrm{M})$ in the presence of the AMPA antagonist CNQX (10 $\mu \mathrm{M})$ for presented in $\boldsymbol{a}$ by determining the activity of $\mathrm{LDH}$ released by dying neurons. Statistical analysis was realized by ANOVA followed by Bonferroni-Dunn's test $(n=16 ; p<0.001)$. c, Transcriptional expression of APP isoforms in neurons exposed to NMDA (50 stimation of neuronal cell death in paradigms presented in c. Statistical analysis was realized by ANOVA followed by Bonferroni-

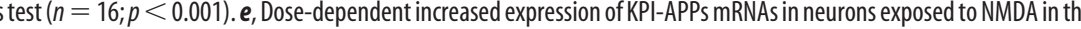
death in paradigms presented in $e$. Note that the $24 \mathrm{~h}$ application of $7.5 \mu \mathrm{M}$ NMDA can lead to neuronal death similar to that observed by treating neurons with $50 \mu \mathrm{m}$ NMDA for $3 \mathrm{~h}$. Statistical analysis was realized by ANOVA followed by Bonferroni-Dunn's test $(n=16 ; p<0.001)$. C, Control.

with specific oligonucleotides for APP isoforms $\mathrm{APP}_{770}, \mathrm{APP}_{751}$, and $\mathrm{APP}_{695}(242,222$, and $401 \mathrm{bp}$, respectively, of PCR product). Conditions of amplification were $30 \mathrm{~s}$ at $95^{\circ} \mathrm{C}, 30 \mathrm{~s}$ at $58^{\circ} \mathrm{C}$, and $1 \mathrm{~min}$ at $72^{\circ} \mathrm{C}$ for 25 or $30-35$ cycles, corresponding to the $50 \%$ of the saturation curve of the PCR products obtained for $\beta$-actin and APP isoforms, respectively. APP primers were designed to flank the alternatively spliced exons (exons 7 and 8) to detect the expression of the three major APP isoforms found in the brain. Oligonucleotide sequences used are as follows: $\beta$-actin sense, 5' GTG GGC CGC TCT AGG CAC AA 3'; gene location 25-45 bp and antisense 5' CTC TTT GAT GTC ACG CAC GAT TTC 3'; 564-540 bp. $\mathrm{APP}_{695}$ oligonucleotides are as follows: sense $5^{\prime}$ GCA CTA ACT TGC ACG ACT ATG GCA TGC TGC TGC CCT G 3'; 500-536 bp and antisense 5' GCT GGC TGC CGT CGT GGG AAC TCG GAC TAC CTC CTC CAC A 3'; 860-1104. APP ${ }_{751}$ oligonucleotides are as follows: sense 5' CTA CCA CTG AGT CTG TGG AG 3'; 848-868 bp and antisense 5' 
SHAM
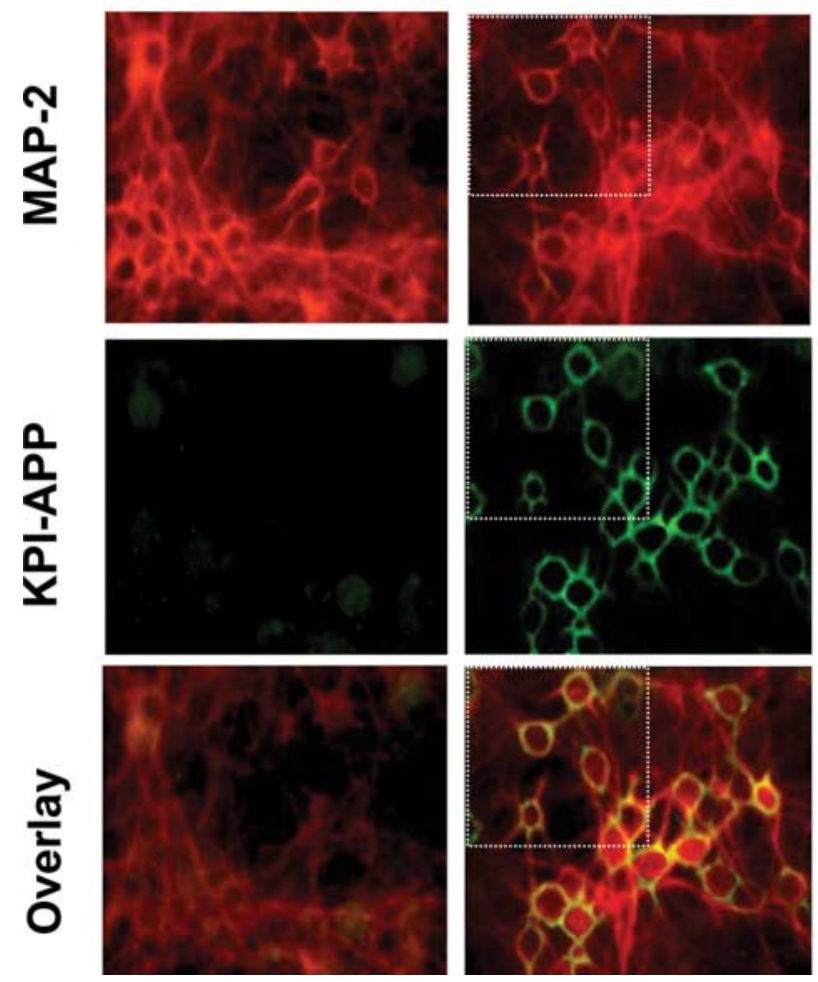

Figure 2. Expression of KPI-APP isoforms in cultured cortical neurons subjected to NMDA receptor activation. KPI-APP expression in neurons after a sublethal exposure of $7.5 \mu \mathrm{m}$ NMDA for $24 \mathrm{~h}$. Neurons were stained with an antibody raised against the neuronal marker MAP-2 (red), and KPI-APP protein expression was determined by using the polyclonal R7 antiserum against the KPI domain of APP (green). KPI-APPs appeared colocalized (yellow) to neuronal plasma membrane when images were overlaid.

Serum deprivation- and staurosporineinduced apoptosis. At 7 DIV, near pure neuronal cultures were transferred during $24 \mathrm{~h}$ into serum-free DMEM in the presence of MK-801 $(10 \mu \mathrm{M})$ to block secondary excitotoxic injury. Cycloheximide $(1 \mu \mathrm{g} / \mathrm{ml})$, a protein synthesis inhibitor, was used to confirm the features of cell death. Neuronal cell death was estimated by counting dying neurons stained with $0.4 \%$ trypan-blue dye.

STP (200 nM) was added for 6 or $12 \mathrm{~h}$ in pure neuronal cultures at 13-14 DIV in serum-free DMEM supplemented with $10 \mu \mathrm{M}$ glycine. MK801 was added to prevent secondary NMDA receptor activation.

$\mathrm{KCl}$-induced depolarizations. $\mathrm{KCl}$ applications $(50 \mathrm{~mm}$ ) were performed for either 3 or $24 \mathrm{~h}$ by incubating 14 -d-old (14 DIV) neuronal cultures in the presence of MK-801 $(10 \mu \mathrm{M})$ and CNQX $(10 \mu \mathrm{M})$ into serum-free DMEM supplemented with glycine $(10 \mu \mathrm{M})$. The L-type $\mathrm{Ca}^{2+}$-channel antagonist, nimodipine $(1 \mu \mathrm{M})$, was used to inhibit the depolarizations induced by $\mathrm{KCl}$.

Calcium signaling. Primary cultures of neurons (14 DIV) were pretreated $(1 \mathrm{~h})$ with the membrane-permeant calcium chelator BAPTA-AM $(10 \mu \mathrm{M})$ before NMDA or $\mathrm{KCl}$ applications. Exposures with the L-type $\mathrm{Ca}^{2+}$ channel inhibitor nimodipine $(1 \mu \mathrm{M})$ were performed for 3 or $24 \mathrm{~h}$, respectively, in the presence or absence of NMDA or KCl.

Western blotting and immunoprecipitation. At the indicated times, cells were harvested in a lysis solution containing $50 \mathrm{~mm}$ Tris- $\mathrm{HCl}, \mathrm{pH}$ 7.6, 1\% NP-40 (Sigma), $150 \mathrm{~mm} \mathrm{NaCl}$, and 2 mM EDTA, with $1 \mathrm{~mm}$ phenylmethylsulfonyl

GCT GGC TGC CGT CGT GGG AAA CAC GCT GCC ACA CAC CGC C 3'; 1028-1104. APP ${ }_{770}$ primers are as follows: sense 5' CTA CCA CTG AGT CTG TGG AG 3'; 848-868 bp and antisense 5' CTT GAG TAA ACT TTG GGA TGA CAC GCT GCC ACA CAC CGC C 3'; 1028-1068. These sequences were designed from the rat APP CDNA sequences corresponding to GenBank accession numbers X14066 and X07648. BDNF oligonucleotides are as follows: sense 5' TGT GCG GAC CCA TGG GAC TC 3'; gene location 75-94 bp and antisense 5' TGT CAC ACA CGC TCA GCT CC 3'; 381-4000 bp. These sequences were designed from the mouse BDNF cDNA sequences corresponding to GenBank accession number AY011461. Amplification was performed in an Eppendorf thermocycler (Eppendorf Scientific, Westbury, NY) with the Promega PCR kit.

All PCR products for $\mathrm{APP}_{770}, \mathrm{APP}_{751}$, and $\mathrm{APP}_{695}$ displayed the expected size and the specificity of the PCR products amplified was confirmed by digestion with restriction enzymes $\left(A l u \mathrm{I}\right.$ for $\mathrm{APP}_{770}$ and $\mathrm{APP}_{695}$; and RsaI for $\mathrm{APP}_{751}$ ).

Finally, agarose gels were acquired with a CCD camera, and twodimension densitometry analysis was determined by using the OptiQuant software (Packard Bioscience, Meriden, CT)

Primary cell cultures. Mouse cortical cultures of neurons were prepared from 14- to 15-d-old embryos as described previously (Rose et al., 1993). After $3 \mathrm{~d}$ in vitro (DIV), neurons were treated with $10 \mu \mathrm{M}$ AraC to inhibit proliferation of non-neuronal cells. All of the experiments were performed on pure neuronal cultures $(>98 \%$ of microtubule associated protein-2 immunoreactive cells) after 12-14 DIV.

Exposure of glutamatergic agonists. AMPA treatment was performed in the presence of the noncompetitive NMDA receptor antagonist MK-801 $(10 \mu \mathrm{M})$ to inhibit secondary NMDA receptor activation. Addition of the AMPA receptor (AMPAR) antagonist CNQX $(10 \mu \mathrm{M})$ was used to block AMPA receptor during NMDA treatment $(7.5$ for $24 \mathrm{~h}$ and $50 \mu \mathrm{M}$ for $3 \mathrm{~h}$ exposure). These conditions induced $<25 \%$ of neuronal cell death as estimated by lactated dehydrogenate (LDH) activity. fluoride (PMSF) in the presence of a protease inhibitor mixture (Sigma). Cell lysates were centrifuged for $10 \mathrm{~min}$ at $12,000 \mathrm{rpm}$, supernatants were isolated, and corresponding pellets were resuspended with the proteases inhibitor-containing lysis buffer to extract membrane-bound proteins. Plasma membranes were solubilized in lysis buffer ( $50 \mathrm{~mm}$ Tris- $\mathrm{HCl}, \mathrm{pH}$ 7.4, $150 \mathrm{~mm} \mathrm{NaCl}, 0.5 \%$ Triton X-100, 1 mм EGTA, 0.1\% SDS, 1\% deoxycholate, $1 \mathrm{~mm}$ PMSF) in the presence of protease inhibitors (Sigma). Once resuspended, membrane lysates were subjected to centrifugation, and the soluble fraction was removed for electrophoresis analysis. Equally, conditioned media were harvested in the presence of $1 \mathrm{~mm}$ PMSF and protease inhibitor mixture to be finally concentrated 10-fold using a vacuum system and desalted using Microcon columns (Amicon, Millipore, Beverly, MA). Protein amounts were determined by the Bradford protein assay (BCA Protein Assay; Pierce, Rockford, IL) and normalized to $20-250 \mu \mathrm{g}$ of protein per sample. Electrophoreses were done on $8 \%$ SDS-polyacrylamide Tris-glycine gels or $16.5 \%$ Tris-tricine gels containing $8 \mathrm{M}$ urea. Thereafter, gels were transferred to a polyvinylidene difluoride (PVDF) membrane (polyscreen membrane; PerkinElmer, Paris, France), and membranes were blocked in nonfat milk containing $3 \%$ bovine serum albumin and probed with the appropriate antiserum. Blots were finally developed with an enhanced chemiluminescence Western blotting detection system (Western Lightning Chemiluminescence Reagent Plus; PerkinElmer).

For immunoprecipitations, aliquots $(500 \mu \mathrm{g})$ of protein extracts were diluted to $500 \mu \mathrm{l}$ with dilution buffer and incubated with appropriate antibody. The mixture was incubated overnight at $4^{\circ} \mathrm{C}$ and mixed with 40 $\mu \mathrm{l}$ of protein G-Sepharose, Fast Flow (Amersham Biosciences, Little Chalfont, UK) for $1 \mathrm{~h}$. The beads were washed twice in Buffer A and twice with Buffer B and then proteins were eluted in $40 \mu \mathrm{l}$ of loading SDSPAGE buffer by boiling. Proteins were fractioned on 6\% Tris-glycine SDS-PAGE gels or $18 \%$ Tris-Tricine SDS-PAGE gels and transferred onto PVDF membrane. 
Fluorescent immunocytochemistry. To detect membrane-bound KPI-APP proteins, murine cortical neurons were washed with PBS and incubated with the R7 antiserum for $1 \mathrm{~h}$ at $37^{\circ} \mathrm{C}$ in serum-free DMEM onto living cells. Cells were then gently washed and fixed with ice-cold $4 \%$ PFA and incubated for $1 \mathrm{~h}$ with the Alexa Fluor 488-conjugated antibody (Invitrogen, Leiden, The Netherlands).

Once KPI-APPs were revealed, neurons were incubated overnight with the MAP-2 antibody. Cells were then washed and incubated for $1 \mathrm{~h}$ with the appropriate secondary biotinconjugated antibody. Antibody-antigen complexes were revealed with streptavidin Alexa Fluor 555 conjugate (Invitrogen).

Antibodies. The monoclonal mouse antibody 22C11 (1:1000; Roche Diagnostics, Meylan, France) corresponding to residues 66-81 of APP was used to identify either membranebound protein or soluble derivatives. The following other primary antibodies/antisera were used: $6 \mathrm{E} 10$ and $4 \mathrm{G} 8$ against $\mathrm{A} \beta 1-17$ and $\mathrm{A} \beta 17-$ 24 , respectively (Signet Laboratories, Dedham, $\mathrm{MA})$, polyclonal antiserum against $\mathrm{APP}_{99-126}$ (Chemicon, Temecula, CA), R7 (1:1000) against KPI-APP proteins, R1736 (1:1000) against $\operatorname{sAPP} \alpha$ (Haass et al., 1992), 192wt (1: 500) against $\mathrm{sAPP} \beta$, FCA3542 (Barelli et al., 1997), APPCter-C17 (1:5000) against APP C terminus (Sergeant et al., 2002), s.c.-6416 (1: 1000 ) against the $\mathrm{C}$ terminus of tumor necrosis factor- $\alpha$ converting enzyme (TACE; Santa Cruz Biotechnology, Santa Cruz, CA), and antibodies raised against MAP-2 (1:200), actin (1: 250), and KPI-APP ${ }_{301-315}(1: 100)$, respectively (Sigma). Rabbit polyclonal antisera R1742 (Bussiere et al., 2002), R600 (Behrouz et al., 1989), and APPCter-C17 are kind gifts from Nicolas Sergeant, Luc Buée, and André Delacourte. Both R1742 an R600 were tested against synthetic $\mathrm{A} \beta_{1-40}$ and $\mathrm{A} \beta_{1-42}$ peptides (Sigma) to determine their specificities (data not shown).

A $\beta$ fluorometric ELISAs. A $\beta$ peptides present in the conditioned culture media were captured with an antibody raised against the $\mathrm{N}$-terminal domain of $A \beta(8-17)$ and revealed with a secondary antibody raised against the C-terminal extremity (40 or 42 -end) of $\mathrm{A} \beta$ (BioSource, Nivelles, Belgium). Recombinant rodent synthetic A $\beta$ s (Calbiochem, La Jolla, CA, San Diego) were used for the calibration curves for each ELISA performed.

TACE activity assay. TACE activity was determined by using the $\alpha$-secretase activity kit and recombinant human TACE (R\&D Systems, Minneapolis, MN). The experimental procedure was performed as described by the manufacturer.

Diffuse head injury model. All procedures were performed in strict compliance with French regulations (D2001-486) and with the EC regulations 96 (Official Journal of European Community L358 12/18/1986) on animal care and use.

The model of diffuse head injury was elaborated as described previously (Hellal et al., 2003). Briefly, Swiss mice weighing 26-28 g (Janvier, France) were anesthetized under $2 \%$ halothane balanced with air and oxygen. Closed head trauma was induced by a $50 \mathrm{~g}$ weight dropped along a stainless-steel string. This experimental paradigm creates a pattern of diffuse degeneration into the brain accompanied with a deficit of the functional outcome (Hellal et al., 2003). At the indicated time, mice presenting a significant deficit of the functional outcome were deeply anesthetized with isoflurane and killed, and their brains were immedi-
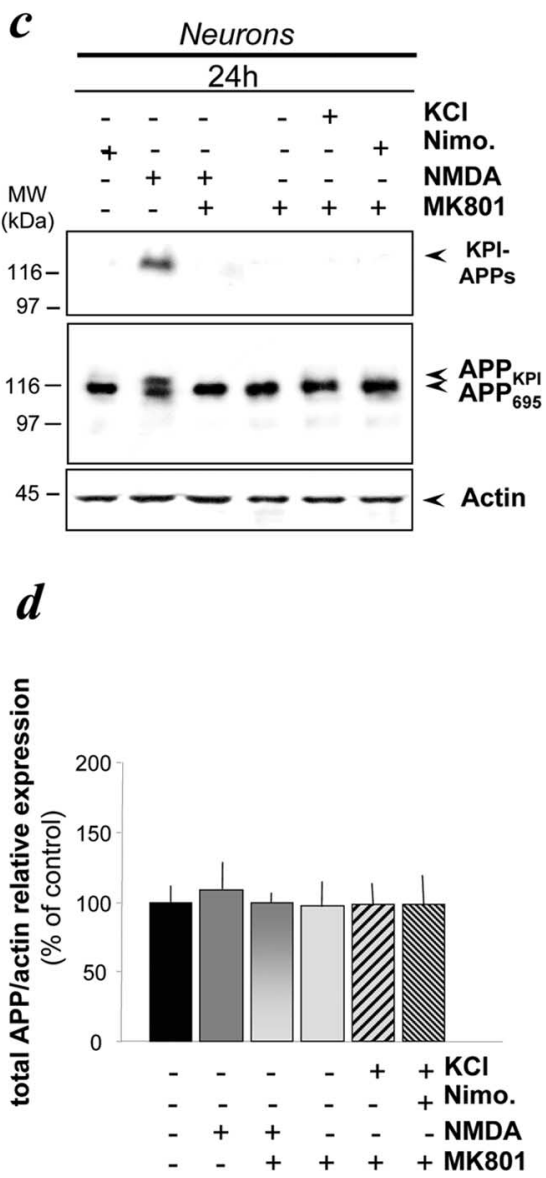

Figure 3. Calcium-dependent KPI-APP expression in neurons after NMDA receptor activation. $\boldsymbol{a}$, Reverse transcription-PCR analysis of APP mRNAs expression after NMDA receptor stimulation in the presence or absence of the membrane-permeant

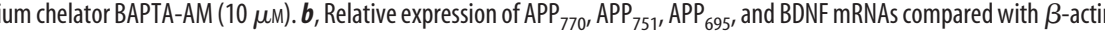
analysis was realized by ANOVA followed by Bonferroni-Dunn's test ( $n=12 \cdot p<0.001)$. Dark bars, Sham-wash control; gray (1) . Blots were rehybridized with an actin antibody to estimate the total amount of proteins loaded. $\boldsymbol{d}$ MK-801-treated neurons; bold-hatched bars, KCl-exposed neurons; hatched bars, coapplication of nimodipine (1 $\mu \mathrm{m})$. C, Control; MW, molecular weight; Nimo., nimodipine.

ately removed and briefly rinsed in chilled saline. Tissue samples were taken vertically from the fresh brain at the site of lesion using a 4-mmdiameter punch and were used for Western blot analysis.

Human brain tissues. The brain tissues used in this study were provided by the Institute for Brain Aging and Dementia Tissue Repository. Neuropathological analyses were performed to determine amyloid plaque burden and tauopathology in the tissue samples. Researchers performing the biochemical analysis of cortical brain extracts were blinded.

Statistical analysis. Results are expressed as mean \pm SD (SD). Statistical analyses were performed with StatView (Abacus, Berkeley, CA) by one-way ANOVA followed by Bonferroni-Dunn's test or Student's $t$ test.

\section{Results}

NMDA exposure induces the neuronal expression of KPI-APPs

After acute brain injuries, a shift in APP mRNA expression occurs altering the balance of generated transcripts from $\mathrm{APP}_{695}$ toward KPI-containing APP (Abe et al., 1991; Kim et al., 1998). The mechanism that sustains this effect remains unresolved but could be connected to the deleterious pathways activated by such insults. To determine the cellular and molecular mechanisms trig- 
$\boldsymbol{a}$
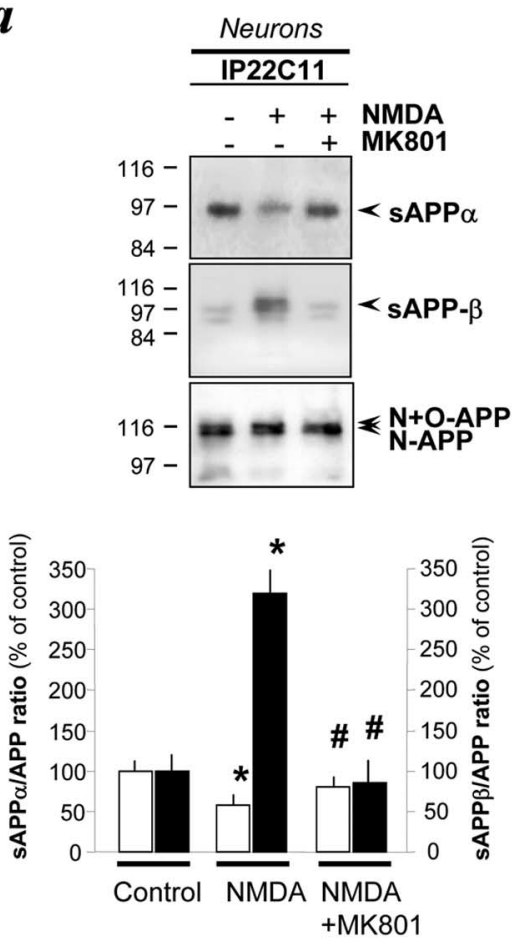

C
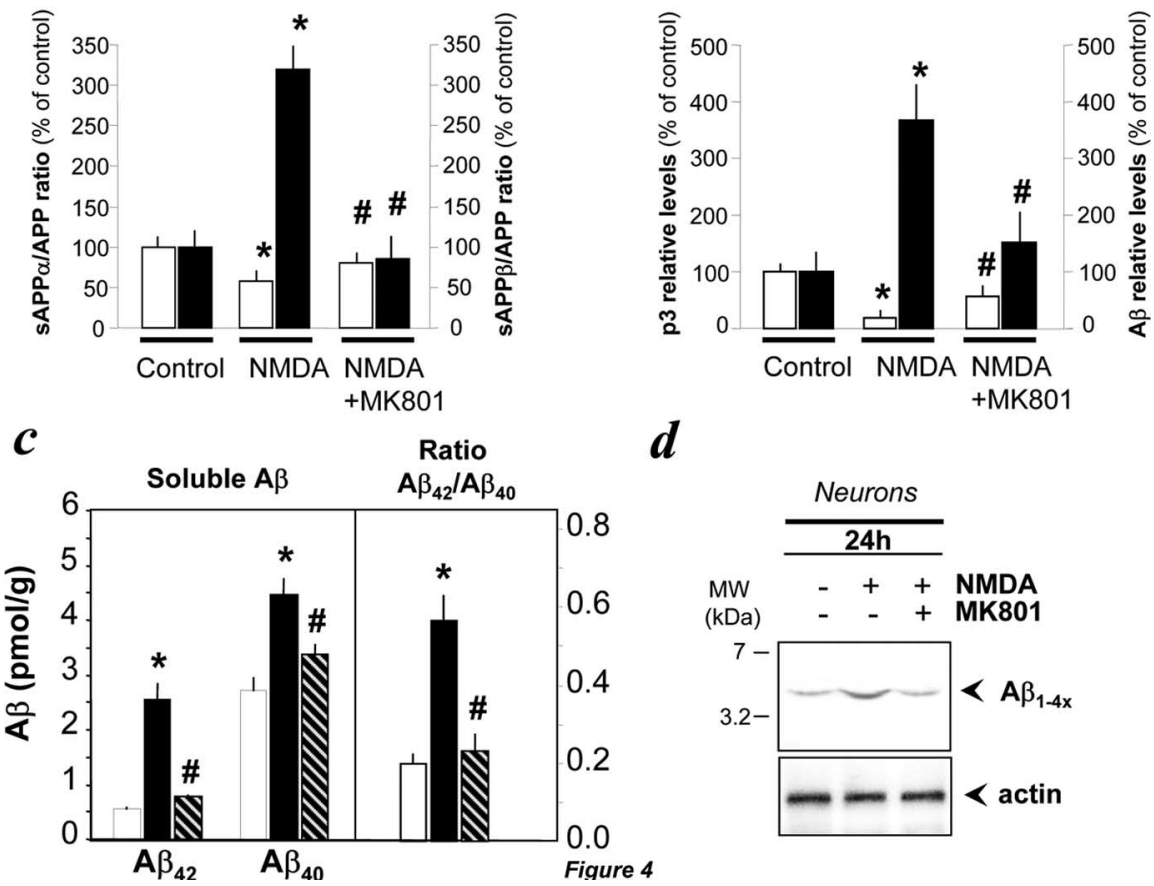

d

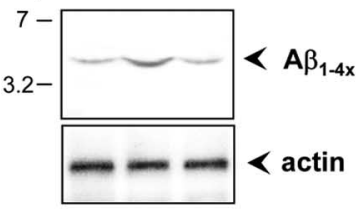

Figure 4. NMDA receptor stimulation leads to an inhibition of sAPP $\alpha$ release and an increased A $\beta$ production. $\boldsymbol{a}$, Immunoprecipitations of SAPP $\alpha$ or SAPP $\beta$ and total sAPPs in conditioned media of cultured neurons treated with NMDA (7.5 $\mu \mathrm{m})$ for $24 \mathrm{~h}$. sAPP $\alpha$ was revealed with the R1736 antiserum, SAPP $\beta$ with the 192 antiserum, and SAPPs with the $22 C 11$ antibody after capturing all APP isoforms with the $22 \mathrm{C} 11$ antibody. sAPPx/total sAPP ratios were estimated by densitometry. Open bars, SAPP $\alpha_{i}$ filled bars, SAPP $\beta$. Results are the mean of four experiments performed in triplicate. Statistical analysis was realized by ANOVA followed by Bonferroni-Dunn's test $\left(n=12 ;{ }^{*} p<0.001\right.$ to control; ${ }^{\#} p<0.02$ to NMDA). $\boldsymbol{b}$, Western blot analysis of extracellular $A \beta$ in neurons after NMDA application for $24 \mathrm{~h}$ by using antisera raised against either the C-terminal extremity of $A \beta_{42}(R 1742)$ (top) or $A \beta_{1-10}$ (R600) (bottom). $p 3$ levels and $A \beta$ levels were estimated by densitometry. Open bars, $p 3$; filled bars, $A \beta$. Results are the mean of four experiments performed in triplicate. Statistical analysis was realized by ANOVA followed by BonferroniDunn's test $\left(n=12 ;{ }^{*} p<0.001\right.$ to control; $\# p<0.001$ to NMDA). c, Quantitative determination of A $\beta$ production by ELISA from the same extracts used in $\boldsymbol{b}$. $\boldsymbol{d}$, Western blot analysis of intracellular $A \beta$ in neurons after NMDA application for $24 \mathrm{~h}$ by using R600 antiserum. Actin levels are shown in the bottom blot. IP22C11, Immunoprecipitated with 22C11; MW, molecular weight.

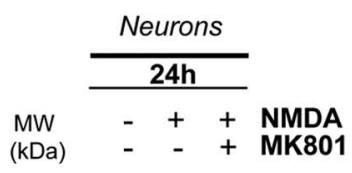

optosis: a gradual shrinkage of the neuronal cell body, a nuclear condensation, and appearance of DNA fragmentation. The addition of cycloheximide $(1 \mu \mathrm{g} / \mathrm{ml})$, a protein synthesis inhibitor, abolished neuronal cell death. These paradigms induced $\sim 40-50 \%$ of neuronal cell death after $24 \mathrm{~h}$. Neither serum deprivation nor staurosporine-induced apoptosis resulted in a modification in the pattern of APP mRNA expression (data not shown).

Morphologically distinct from apoptosis, excitotoxicity is a process characterized by a prominent and early cell swelling. To test the possibility that this neuronal cell death mechanism could alter the transcription of APP, cultured neurons were exposed to excitotoxic paradigms. To induce excitotoxicity, we incubated cortical neurons with glutamatergic agonists: NMDA (50 $\mu \mathrm{M})$ and AMPA (50 $\mu \mathrm{M}$ ) for $30 \mathrm{~min}, 1 \mathrm{~h}$, and $3 \mathrm{~h}$. These treatments resulted in $<20 \%$ of neuronal cell death at $3 \mathrm{~h}$ (Fig. 1). Although AMPA application (in the presence of MK-801, a non competitive NMDA antagonist to avoid secondary NMDAR activation) did not modify the pattern of APP mRNA expression (Fig. 1a), NMDA exposure induced the neuronal expression of KPIAPP transcripts and simultaneously a decrease in $\mathrm{APP}_{695}$ mRNA expression as early as $30 \mathrm{~min}$ after NMDA exposure (Fig. 1c). This effect was abolished by the coapplication of the NMDAR antagonist, MK-801, at $10 \mu \mathrm{M}$. Confirming the previous findings, this increased neuronal KPI$\mathrm{APP} / \mathrm{APP}_{695}$ mRNA ratio was also induced by lower doses of NMDA (from 5 to $12.5 \mu \mathrm{M})$ applied for $24 \mathrm{~h}$ (Fig. 1e). Estimated posttreatment assessment of neuronal death revealed that a low concentration of NMDA $(7.5 \mu \mathrm{M})$ for $24 \mathrm{~h}$ induced neuronal expression of mRNA KPI-APPs without significantly affecting neuronal survival (Fig. 1f). Consequently, double immunocytochemical analysis performed with the R7 polyclonal antiserum raised against the KPI domain of APP (Refolo et al., 1989) and with an antibody raised against the neuronal gering this upregulation of KPI-APP, we exposed primary cultures of murine cortical neurons (containing $<2 \%$ of glial cells) to different experimental paradigms promoting apoptosis or necrosis.

Although acute neuronal injury is thought to result from an excessive release of excitatory amino acids and the subsequent activation of their postsynaptic receptors, various clues have emerged suggesting that apoptotis may also exert a significant role in traumatic neuronal injury (Linnik et al., 1993; MacManus et al., 1993; Schulz et al., 1999). In primary cortical cultures, both serum deprivation (7 DIV) and application of the protein kinase inhibitor staurosporine (14 DIV) induced typical features of ap- marker MAP-2 demonstrated that a $24 \mathrm{~h}$ exposure to $7.5 \mu \mathrm{M}$ NMDA induced KPI-APP immunoreactivity at the neuronal plasma membrane (Fig. 2).

Based on these findings, NMDA-mediated excitotoxic but not apoptotic experimental paradigms were able to mimic the alteration of APP transcripts previously reported after acute brain injuries.

Calcium influx through NMDA receptors induces membrane expression of KPI-APP

Because massive calcium $\left(\mathrm{Ca}^{2+}\right)$ influx through the NMDARs has been shown extensively to be a critical event in excitotoxic 
neuronal death (MacDermott et al., 1986), we tested the possibility that the increase in the KPI-APP/APP ${ }_{695}$ ratio observed in neurons exposed to NMDA was mediated by an increase in intracellular $\mathrm{Ca}^{2+}$ concentration.

First, we pretreated neuronal cultures with the membrane-permeant $\mathrm{Ca}^{2+}$ chelator BAPTA-AM $(10 \mu \mathrm{M}) 1 \mathrm{~h}$ before NMDA treatment. In these conditions, the NMDA-dependent increase in neuronal $\mathrm{APP}_{770}$ and $\mathrm{APP}_{751}$ mRNA expression (Fig. $3 a$ ) was fully blocked by intracellular $\mathrm{Ca}^{2+}$ chelation, implying a calciumdependent control of KPI-APPs mRNA expression in neurons.

To determine whether this response was selectively triggered by NMDAR activation, we studied whether calcium entry through voltage-sensitive calcium channels (VSCCs) activated by $\mathrm{KCl}$-induced depolarizations in the presence of NMDAR and AMPAR antagonists would result in a similar modification of APP transcription. As demonstrated previously (Tao et al., 1998; West et al., 2001), KCl exposure promoted the neuronal expression of mRNA encoding for BDNF. This upregulation of BDNF transcripts was abolished by the coapplication of an L-type VSCC blocker (nimodipine at 1 $\mu \mathrm{M}$ ), whereas the application of NMDA did not affect BDNF mRNA neuronal expression (Fig. 3b). In contrast, $\mathrm{KCl}-$ induced depolarizations failed to modify the neuronal pattern of APP mRNA expression (Fig. 3b).

At a protein level, immunoblotting analysis with the R7 antiserum raised against the KPI domain of APP confirmed that neurons do not express a detectable amount of KPI-APPs in control conditions (Fig. 3c). However, $7.5 \mu \mathrm{M}$ NMDA exposure resulted in a marked increase in KPI-APP, whereas treatment with $\mathrm{KCl}$ did not modify neuronal KPI-APP expression. Accordingly, expression of fulllength APPs was determined by using the antibody 22C11, raised against the $\mathrm{N}$ terminus of APP ectodomain (residues 66-81) and confirmed the upregulation of APP higher molecular weight isoforms containing the KPI domain (Fig. $3 c$ ). Densitometric quantification of the blots revealed no overall change of total APP levels expressed by neurons but indicated that after NMDAR activation, $\sim 30 \%$ of the total neuronal pool of APPs is a KPI-containing isoform (Fig. $3 d$ ).

Overall, these results indicate that the influx of $\mathrm{Ca}^{2+}$ resulting from a sublethal activation of the NMDA receptor controls the induction of the neuronal expression of KPI-APPs.

Neuronal KPI-APP expression enhances $A \beta$ production and reduces $\boldsymbol{\alpha}$-secretase end products

Because KPI-containing APPs have been shown to be more amyloidogenic than $\mathrm{APP}_{695}$ (Ho et al., 1996), we investigated the influence of NMDA-induced KPI-APP expression in neurons on c

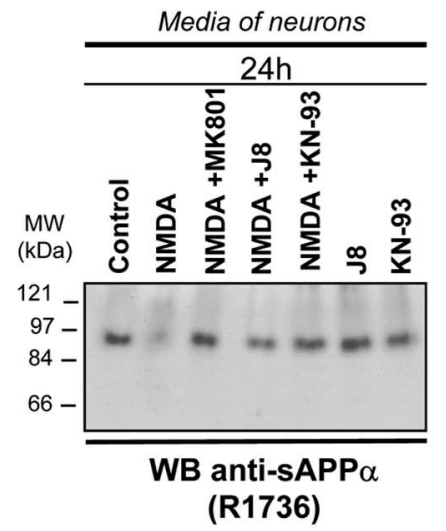

$d$

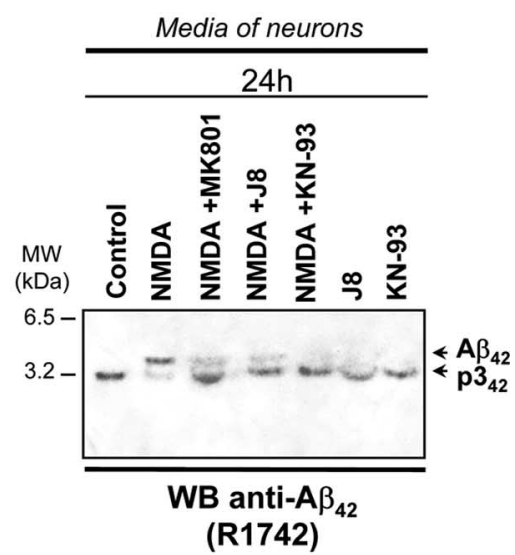

(R1742)

Figure 5. NMDA-dependent $A \beta$ production in neurons is mediated by a calmodulin/calmodulin kinase axis. $\boldsymbol{a}$, Reverse $\mu \mathrm{M})$ for $24 \mathrm{~h}$ in the presence of $10 \mu \mathrm{M}$ CNOX plus $1 \mu \mathrm{m}$ nimodipine and with or without the pretreatment for $1 \mathrm{~h}$ of an inhibitor of either $1 \mu \mathrm{m}$ calmodulin (J8) or $10 \mu \mathrm{m}$ calmodulin kinase-II (KN-93). № Ab, № antibody. c, Immunoblotting analysis of sAPP $\alpha$ eneration in conditioned media of cultured neurons incubated in the same conditions indicated in $\boldsymbol{b}$. $\boldsymbol{d}$, Western blot analysis of $A \beta$ generation in murine-cultured neurons incubated in the same conditions indicated in $\boldsymbol{b}$. IP 22C11, Immunoprecipitated with 22C11; WB, Western blot; MW, molecular weight.

the APP processing. To this end, we performed immunoprecipitation/Western blot analysis from the conditioned media of cultured neurons to estimate the respective levels of APP derivatives secreted by neurons after NMDA application.

As reported previously (Haass et al., 1993), sAPP $\alpha$ is predominant in the conditioned media of control neuronal cultures. A $24 \mathrm{~h}$ NMDA exposure dramatically reduced sAPP $\alpha$ immunoreactivity (Fig. 4a). The coapplication of MK-801 restored the production of $\operatorname{sAPP} \alpha$ to basal levels. This observed lowering of sAPP $\alpha$ immunoreactivity after NMDAR stimulation is accompanied by an elevation of $\mathrm{AAPP} \beta$, whereas the total amount of soluble APP molecules (sAPPx) remained unchanged (Fig. 4a). Similarly to $\operatorname{SAPP} \alpha$, cotreatment with MK-801 prevented the shift toward sAPP $\beta$ genesis induced by NMDA receptor activation. These data were quantified by densitometry analysis for both sAPP $\alpha /$ APP and sAPP $\beta /$ APP ratios (Fig. $4 a$ ).

Because $\beta$-secretase activity is necessary to $\mathrm{A} \beta$ genesis, the amounts of $A \beta$ and $\mathrm{p} 3$ peptides present in the neuronal conditioned culture media were evaluated by using an antiserum raised 

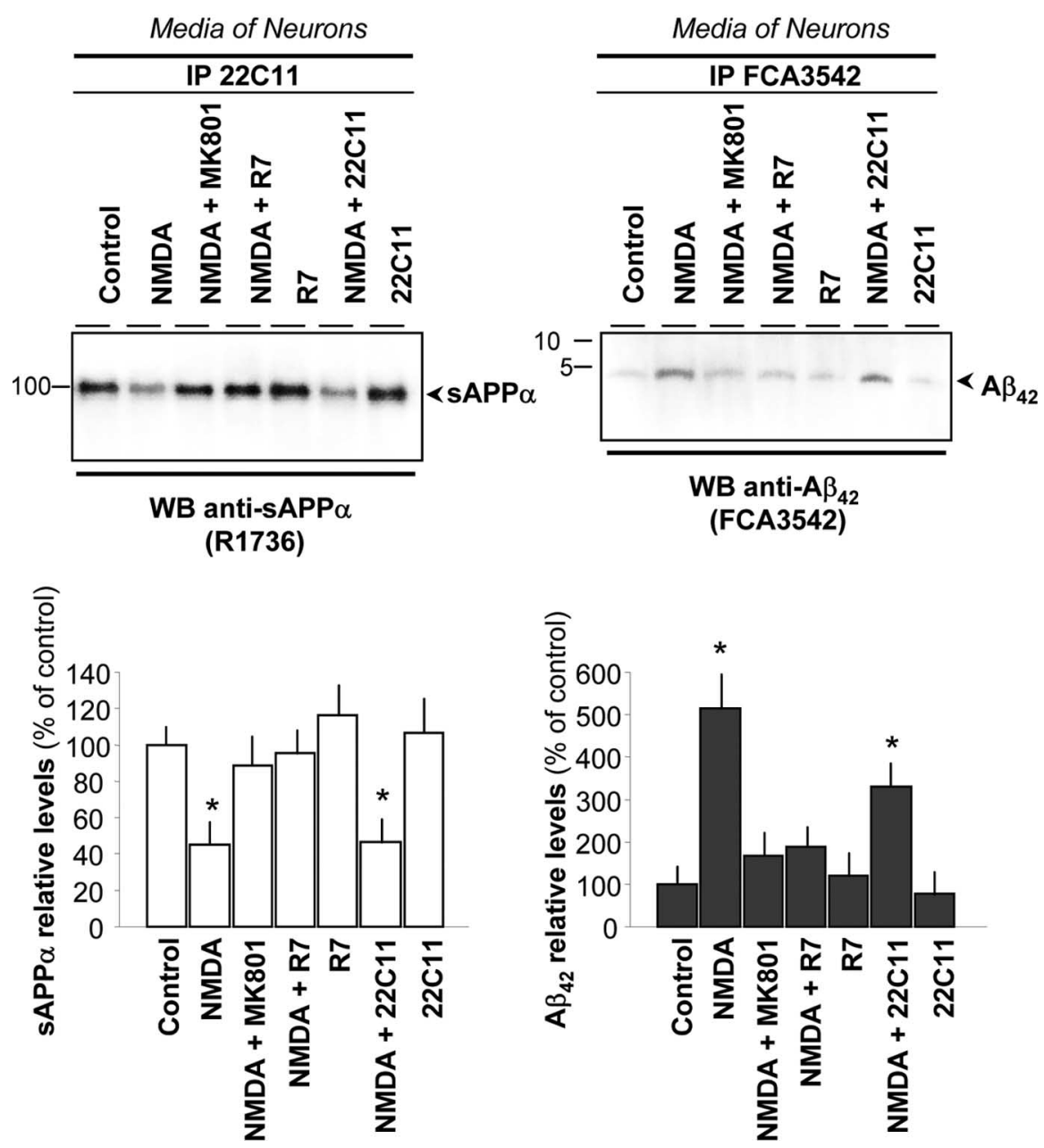

Figure 6. KPI-dependent $A \beta_{42}$ production in cortical neurons is reversed by the coincubation of a blocking antibody raised against the KPI domain. $\boldsymbol{a}$, Immunoprecipitation of SAPP $\alpha$ generation in conditioned media of cultured neurons treated with NMDA $(7.5 \mu \mathrm{M})$ in the presence of an antibody raised against either the KPI domain of APP or the N terminus of APP (residues 66 - 81) for $6 \mathrm{~h}$. SAPP $\alpha$ levels were estimated by densitometry. Results are the mean of three experiments performed in triplicate. Statistical analysis was realized by ANOVA followed by Bonferroni-Dunn's test $\left(n=9 ;{ }^{*} p<0.01\right.$ to control). $\boldsymbol{b}$, Western blot analysis of $A \beta_{42}$ generation in neurons in the same protein samples used in $\boldsymbol{a}$. Note that $A \beta$ was immunoprecipitated and revealed with the FCA3542 antiserum against $A \beta_{42}$. Levels of $A \beta$ were estimated by densitometry. Statistical analysis was realized by ANOVA followed by Bonferroni-Dunn's test $\left(n=9\right.$; ${ }^{*} p<0.01$ to control). IP 22C11, Immunoprecipitated with 22C11; WB, Western blot.

against the C-terminal extremity of $\mathrm{A} \beta_{42}$ termed R1742 to immunoprecipitate both $\mathrm{A} \beta$ and $\mathrm{p} 3$ (Fig. $4 b$ ). In control conditions, $\mathrm{p} 3$ was predominant in the extracellular medium. Incubation with $7.5 \mu \mathrm{M}$ NMDA for $24 \mathrm{~h}$ resulted in an elevation of secreted $\mathrm{A} \beta_{42}$ that was abolished by the coapplication of MK-801 (Fig. $4 b$ ).

To confirm that the peptide identified in the extracellular media after NMDA stimulation was $A \beta$, an additional antiserum, termed R600, raised against $A \beta_{1-10}$ was used to detect $A \beta$ under the same experimental conditions. This experiment strengthened our previous observations that NMDA exposure led to an elevation of soluble $\mathrm{A} \beta$ after $24 \mathrm{~h}$ (Fig. $4 b$ ).

To finally quantify our findings, we performed an $A \beta$ enzymelinked immunosorbent assay (ELISA) on harvested conditioned media. After $24 \mathrm{~h}$, a sublethal NMDA exposure induced a moderate elevation of $\mathrm{A} \beta_{40}$ production and an approximate fivefold increase in the amount of $\mathrm{A} \beta_{42}$ present in the conditioned media
(Fig. 4c). Of note, a similar increase in intraneuronal $\mathrm{A} \beta$ was observed (Fig. $4 d$ ), suggesting an elevation of $A \beta$ production.

To resume, the NMDA-dependent expression of KPI-APP in neurons is accompanied by an enhanced formation of components of the amyloidogenic pathway (i.e., sAPP $\beta$ and $A \beta$ ).

The calcium/calmodulin-dependent kinase axis is required for the induction of KPI-APPs and A $\boldsymbol{\beta}_{42}$

To identify the intracellular mediators involved in the NMDA-induced increase in $\mathrm{KPI}-\mathrm{APP} / \mathrm{APP}_{695}$ ratio in neurons, we evaluated the implication of two $\mathrm{Ca}^{2+}$. activated enzymes associated with the NMDAR: the calmodulin (CaM) and the CaM-dependent kinase II (CaMKII) (Husi et al., 2000) by using selective inhibitors of either CaM (J8) or CaMKs (KN-93) (Fig. 5). A $1 \mathrm{~h}$ pretreatment with each inhibitor blocked both the neuronal KPI-APPs mRNA appearance induced by NMDA (at $50 \mu \mathrm{M}$ for $3 \mathrm{~h}$ ) (Fig. $5 a$ ) and the membrane expression of the KPI-APP proteins induced by a lower dose of NMDA (at $7.5 \mu \mathrm{M}$ for $24 \mathrm{~h}$ ) (Fig. 5b). These results demonstrate the involvement of the CaM/CaMK axis in the shift expression toward KPI-APP expression induced by NMDAR activation in cortical neurons. Subsequently, inhibitors of the CaM/CaMK axis restored the production of $\operatorname{sAPP} \alpha$ (Fig. $5 c$ ) and abolished the increase in $\mathrm{A} \beta$ in the neuronal conditioned bathing media after NMDA incubation (Fig. 5d).

\section{Incubation with anti-KPI antibodies prevents NMDA-induced \\ $A \boldsymbol{\beta}$ production}

To validate the idea that KPI-APP expression at the neuronal membrane played a pivotal role in the increased $\mathrm{A} \beta$ production after NMDAR activation, we exposed cortical neurons to the R7 antiserum in the presence of NMDA (at $7.5 \mu \mathrm{M}$ ). Incubation with the R7 antiserum abolished both the NMDA-induced decrease in $\operatorname{sAPP} \alpha$ (Fig. $6 a$ ) and $\mathrm{A} \beta_{42}$ production (Fig. $6 b$ ). To validate the effect observed with the R7 antiserum, a commercially available polyclonal antibody developed to detect the KPI domain of $\mathrm{APP}_{770}$ (residues 301-315) was used under similar conditions and confirmed our previous findings (data not shown). Because the blockade of NMDA-induced $\mathrm{A} \beta$ production observed after R7 antiserum incubation could be attributable to a nonspecific alteration of APP processing by the antiserum, we performed parallel experiments either with the 22C11 monoclonal antibody raised against the $\mathrm{N}$ terminus of APP ectodomain (APP) and with a polyclonal antiserum raised against $\mathrm{APP}_{99-126}$ (data not shown) in the presence of NMDA. In contrast to R7, both antibodies did not reverse NMDA-induced $\mathrm{A} \beta_{42}$ elevation (Fig. $6 a, b$ ).

Thus, our findings indicate that the expression of KPI-APP 
proteins coincides with a shift from a dominant $\alpha$-secretase to a $\beta$-secretase processing of APP after NMDAR activation.

\section{The KPI domain of APP interacts with the $\alpha$-secretase candidate TACE}

To further understand how the neuronal expression of KPI-APP molecules could alter $\alpha$-secretase activity, we determined whether the $\alpha$-secretase candidate, TACE, interacted correctly with KPI-APP (Buxbaum et al., 1998; Skovronsky et al., 2000).

To detect TACE in neurons, we used an antibody raised against its $\mathrm{C}$ terminus that allowed us to identify the $120 \mathrm{kDa}$ fulllength precursor (containing a prodomain), the $100 \mathrm{kDa}$ mature form and the $60 \mathrm{kDa}$ truncated form of TACE (Schlondorff et al., 2000; Skovronsky et al., 2000) (Fig. 7a). When TACE was immunoprecipitated from neuronal lysates, proTACE, mature TACE, and cleaved TACE were detected. Neither global nor respective expression levels of TACE isoforms were modified by NMDA application.

Although no interaction was observed between KPI-APP and TACE in control conditions, immunoprecipitation with the TACE antibody revealed with $\mathrm{R} 7$ revealed a direct interaction between TACE and KPI-APP in neurons exposed to a sublethal NMDA treatment (Fig. 7a, lane 3). Coapplication of MK-801 inhibited this association between KPI-APPs and TACE (Fig. 7a, lane 4). Because neuronal TACE interacts with KPI-APP, we tested whether this association affects TACE activity. To this end, we monitored neuronal TACE activity under these experimental conditions by using a TACE activity assay (Fig. $7 b$ ). NMDA receptor activation reduced neuronal TACE activity by $\sim 80 \%$ compared with controls [59 \pm 40 vs $294 \pm 39$ arbitrary units (AU)]. The coincubation of R7 antibody with NMDA restored the neuronal $\alpha$-secretase activity to basal level (257 $\pm 27 \mathrm{AU})$, whereas the monoclonal antibody $22 \mathrm{C} 11$ or the polyclonal antiserum against $\mathrm{APP}_{99-126}$ failed to restore normal TACE activity.

To resume, after a sublethal NMDA exposure, neurons express KPI-APPs that interact with neuronal $\alpha$-secretase candidate TACE and inhibit TACE function.

\section{$\mathrm{A} \beta$ production is increased after traumatic brain injury}

To validate the relevance of our in vitro findings, we examine the influence of TBI on APP expression and processing. The model of TBI used creates a pattern of diffuse degeneration triggered by increased concentration of extracellular glutamate (Arundine and Tymianski, 2004). First, we examined the time course of cortical APP expression in tissue samples of mice subjected to TBI by immunoblot. Specific labeling was densitometrically measured and normalized to controls. In membrane extracts, KPIAPP expression increased in ipsilateral cortices as early as $6 \mathrm{~h}$ after TBI $(172 \pm 33 \% ; p<0.05)$ and persisted $24 \mathrm{~h}$ later $(396 \pm 92 \%$; $p<0.01$ ) (Fig. 7a). This increase in KPI-containing isoforms was accompanied with the accumulation of C-terminal fragment- $\beta$ $(\mathrm{CTF}-\beta)$ and a concomitant reduction of CTF- $\alpha$ (52 $\pm 9 \%$; $p<$ 0.01 ), suggesting a shift from a predominant $\alpha$-secretase to $\beta$-secretase processing of APP. To confirm these findings, sAPP $\alpha$ and $\mathrm{A} \beta$ levels were estimated in soluble protein extracts (Fig. $7 b$ ). Six hours after TBI, sAPP $\alpha$ production was downregulated by $\sim 50 \%(51 \pm 16)$, whereas $4 \mathrm{G} 8$-immunoreactive $\mathrm{A} \beta$ levels were increased above the detection limit of our assay. Eighteen hours later, $\operatorname{sAPP} \alpha$ levels were reduced to $\sim 35 \%(34 \pm 16)$ of naive brain levels and soluble $\mathrm{A} \beta$ amounts elevated to nearly twofold $(187 \pm 15 \%)$ when compared with the 6 h post-TBI time point. Overall, these in vivo data demonstrate that TBI induced a modification of APP and A $\beta$ expression pattern similar to the modification observed in cortical neurons exposed to NMDA, suggesting that NMDAR activation governs APP expression and processing in the brain.

\section{Formation of KPI-APP/TACE complex is associated with increased soluble $\mathrm{A} \boldsymbol{\beta}$ levels in $\mathrm{AD}$ brains}

To further validate these experimental findings obtained in rodents, we examined the presence of the TACE/KPI-APP complex in brain tissues of $\mathrm{AD}$ patients and age-matched controls. In membrane preparations from AD patients, the KPI-APPs/TACE complex was increased by $\sim 2.8$-fold in $\mathrm{AD}$ brains when compared with controls $(2.86 \pm 0.71 ; n=3)$ (Fig. $8 c, d)$. In addition to the presence of the KPI-APP/TACE complex, sAPP $\alpha$ levels were also reduced in $\mathrm{AD}$ brains by $20 \%$ compared with controls (Fig. $8 e, f)$. Finally, the levels of soluble $\mathrm{A} \beta$ were higher in $\mathrm{AD}$ brain extracts than in age-matched controls (Fig. $8 e, g$ ). Of note, the soluble $\mathrm{A} \beta$ levels obtained from $\mathrm{AD}$ brains were not directly correlated to the plaque loads measured previously. Overall, these results confirm that the KPI-APP/TACE complex is related to a reduced sAPP $\alpha$ levels and to an enhanced production of soluble $\mathrm{A} \beta$ peptides in $\mathrm{AD}$ brains.

\section{Discussion}

Because patients who previously suffered from brain trauma or stroke have an increased probability to develop amyloid plaques (Nagy et al., 1997; Snowdon et al., 1997), acute brain disorders 


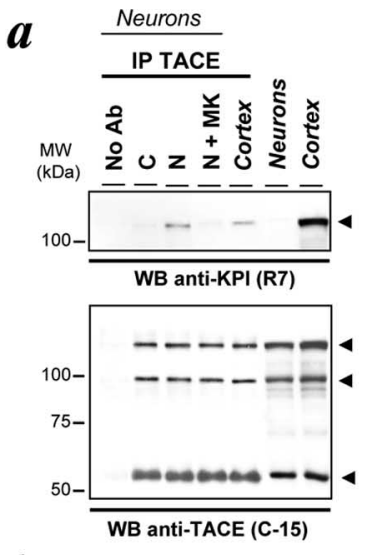

b
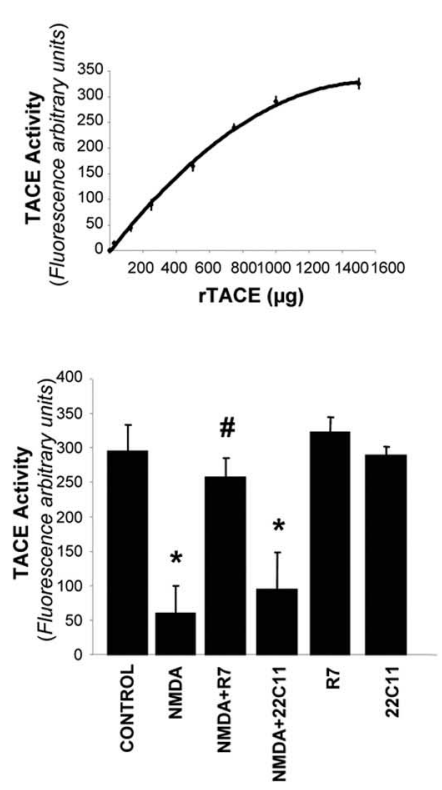

c

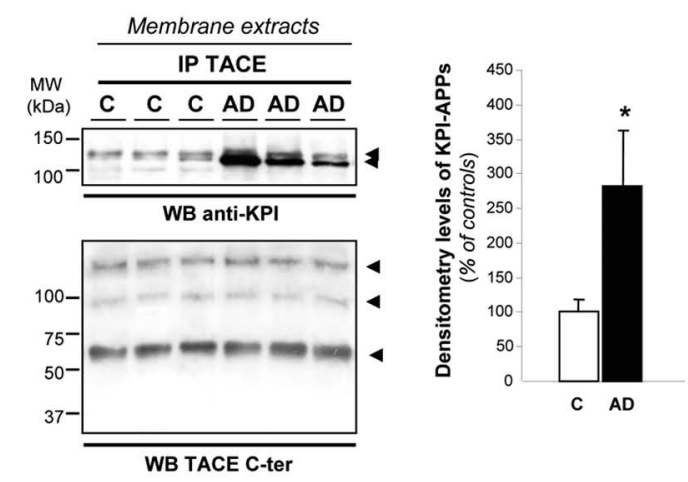

$\boldsymbol{e}$

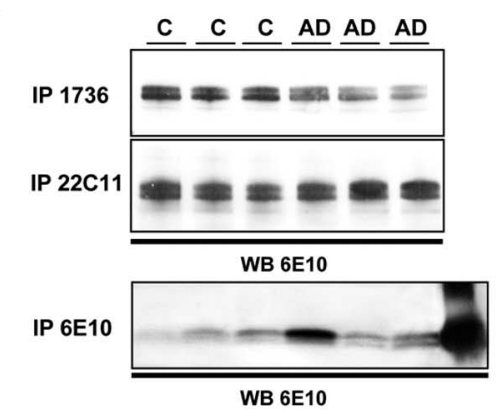

$f$

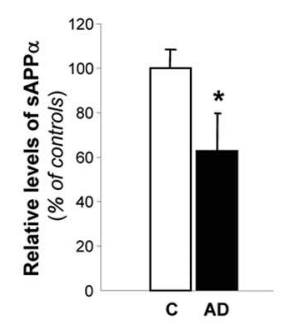

$\boldsymbol{d}$
Figure 8. KPI-APP immunoprecipitates with $\alpha$-secretase candidate TACE in neurons stimulated by NMDA and inhibits TACE function. $\boldsymbol{a}, \mathrm{KPI}-\mathrm{APP}$ s were immunoprecipitated (IP) with an anti-TACE polyclonal antibody and revealed with either R7 (top blot) or anti-TACE antibody (bottom blot). Anti-TACE antibody recognizes all forms of TACE (pro-, mature, and cleaved). № Ab, № antibody. $\boldsymbol{b}$, TACE activity assay was validated by using an increasing concentration of recombinant TACE (rTACE) (top). TACE activity was determined in cultured cortical neurons in the same conditions described in Figure 6 (bottom). Statistical analysis was realized by ANOVA followed by Bonferroni-Dunn's test ( $n=24 ;{ }^{*} p<0.001$ to control; ${ }^{\#} p<0.01$ to NMDA). c, KPI-APPs were immunoprecipitated with an anti-TACE polyclonal antibody and revealed with either the rabbit polyclonal antibody against

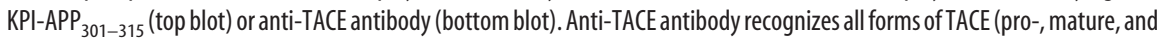
(leaved). $\boldsymbol{d}$, Densitometry analysis of KPI-APP relative levels expressed as percentage of controls. Results are the mean of three experiments performed in triplicate. Statistical analysis consisted of a $t$ test analysis ( $n=3 ;{ }^{*} p<0.01$ to control). $\boldsymbol{e}$, Immunoblotting analysis of SAPP $\alpha, A P P$, and $A \beta$ in human brain soluble extracts. SAPP $\alpha, A P P$, and $A \beta$ were immunoprecipitated using R1736, 22C11, or 6E10, respectively, and detected with 6E10. R1736 recognizes $N+0$ - and N-glycosylated sAPP $\alpha$, and 22 C11 detects both $A P P_{695}$ and KPI-APPs, whereas $6 E 10$ is raised against $A \beta_{1-17}$ (i.e., $A \beta 1-x$ and $A \beta 11-x$ ). The last lane of the Western blot for $A \beta$ (bottom gel) corresponds to synthetic $A \beta_{42}$ used as a standard. $\boldsymbol{f}, \boldsymbol{g}$, Densitometric analysis of sAPP $\alpha$ and total $A \beta$ relative levels expressed as a percentage of controls. Results are the mean of three experiments performed in triplicate. Statistical analysis consisted of a $t$ test analysis ( $n=3 ;{ }^{*} p<0.01$ to control). C, Age-matched controls; AD, Alzheimer's disease brain extracts; WB, Western blot; MW, molecular weight.

injury (Lee et al., 1999). Our major findings are as follows. First, in primary cortical neuronal cultures, sublethal NMDAR activation triggered a shift in APP expression toward KPI-APPs, an effect mediated by $\mathrm{Ca}^{2+}$ entry through the NMDAR and a subsequent CaM/CaMK activation. Second, the neuronal expression of KPI-APPs after NMDAR activation favor $\beta$-secretase processing of APP instead of normally dominant $\alpha$-secretase cleavage and consequently increased $\mathrm{A} \beta$ production and secretion in the culture media. Third, TBI produces a similar modification of the pattern of APP expression and A $\beta$ production in the injured tissue. Fourth, this effect resulted from a marked inhibition of TACE activity after neuronal expression of KPI-APPs. Finally, the formation of KPIAPP/TACE complexes is associated with reduced sAPP $\alpha$ levels and enhanced soluble $\mathrm{A} \beta$ levels in $\mathrm{AD}$ brains.

Murine cortical cell cultures have been used extensively to explore the molecular mechanisms involved in the perturbation of cellular homeostasis induced by acute brain injuries. We studied the expression pattern of APP in primary neuronal cultures (Rose et al., 1993) exposed to different paradigms of cell death identified during cerebral ischemia: apoptosis and excitotoxic necrosis. Although neither apoptosis nor AMPA exposure altered the pattern of expression of APP mRNA, application of NMDA increased the neuronal transcription of KPI-APP proteins and decreased the amount of mRNA encoding for the normally dominant $\mathrm{APP}_{695}$. The modification of APP transcripts described in the present study is in agreement with a previous report indicating that glutamate exposure induced the expression of KPIAPPs in neurons (Willoughby et al., 1995). In addition, we demonstrate that this modification of APP expression is a result of an NMDA-mediated $\mathrm{Ca}^{2+}$ influx and subsequent $\mathrm{CaM} / \mathrm{CaMK}$ axis activation. Because proteomic analysis of the NMDAR-adhesion protein-signaling complexes has revealed that both CaM and CaMKII are linked to the $\mathrm{C}$ terminus of the NMDAR subunits, these enzymes have been identified as a preferential enzymatic system involved in converting NMDA-mediated $\mathrm{Ca}^{2+}$ influx into kinase activation (Husi et al., 2000; Husi and have been identified as an important environmental risk for developing $\mathrm{AD}$ (Cotman et al., 1996). However, the molecular mechanism that mediates this effect remains unclear. To address this question, we studied the expression pattern of APP and the production of $A \beta$ in primary neuronal cultures subjected to necrosis and apoptosis, two different biochemical pathways leading to neuronal cell death that have been identified in acute brain
Grant, 2001). Thus, after NMDAR activation, it can be hypothesized that CaMKII modifies the neuronal profile of APP mRNA transcripts. This hypothesis is strengthened by a recent report that demonstrated the implication of $\mathrm{CaM} / \mathrm{CaMK}$ axis in a $\mathrm{Ca}^{2+}$. mediated alternative splicing of mRNA in neurons (Xie and Black, 2001).

The neuronal expression of KPI-APP proteins induced by 
NMDAR activation leads to a predominant $\mathrm{A} \beta$ secretion instead of peptide p3, revealing a shift from an $\alpha$-secretase toward $\beta$-secretase driven proteolysis of APP. This shift seems to be mediated by the KPI region of APP. Indeed, although the exact nature of the interaction between KPI-APP molecules and $\alpha$-secretase candidate TACE remains to be further analyzed, the incubation of blocking antibodies raised against the KPI domain reversed the amyloidogenic effect of NMDA-induced expression of $\mathrm{APP}_{770}$ and $\mathrm{APP}_{751}$ without affecting the overall APP expression level or the shedding of its ectodomain. The influence of KPI-APP expression on secretase activities has been approached previously. Ho et al. (1996) have demonstrated that the transfection of KPI-APP in murine neuroblastoma cell lines induced a more drastic reduction of sAPP $\alpha$ than the transfection of $\mathrm{APP}_{695}$, suggesting that KPI-APP is more amyloidogenic than $\mathrm{APP}_{695}$. Moreover, the murine transgenic model of AD expressing KPIcontaining APP elicit amyloid plaques at 6 months of age compared with 10-12 months for models using APP lacking the KPI domain (Hsiao et al., 1996; Sturchler-Pierrat et al., 1997; Hsiao, 1998). These findings are consistent with the idea of a pivotal role of KPI isoforms in A $\beta$ amyloidosis (Moir et al., 1998). If the neuronal increase in KPI-APP does promote amyloidosis, the most likely mechanism would be by either altering $\mathrm{A} \beta$ catabolism or by driving the processing of APPs from $\alpha$-secretase to $\beta$-secretase. In the former scenario, it could be speculated that KPI-APP proteins could inhibit serine proteases that normally degrade A $\beta$. One caveat for this postulate would be that $\operatorname{sAPP} \alpha$ levels should also be altered following the modulation of $A \beta$. In our studies, it was not the case, because sAPP $\alpha$ levels were decreased and $A \beta$ levels increased, suggesting that the potential inhibition of $\mathrm{A} \beta$ degradation by serine proteases is not modified by the neuronal expression of KPI-APP molecules. However, we evidenced the formation of a complex between $\alpha$-secretase candidate TACE and neuronal KPI-APPs after NMDA exposure that resulted in an inhibition of TACE activity. Accordingly, this effect led to a shift from a predominant $\alpha$-secretase to $\beta$-secretase cleavage of APP molecules.

In addition to the enhanced formation of $A \beta$ resulting from this shift and its well known deleterious effects on neuronal survival, the lowering of $\operatorname{sAPP} \alpha$ in the extracellular compartment might have important consequences for stressed neuronal cells, because sAPP $\alpha$ molecules have been shown to display neuroprotective effects (Mattson et al., 1993). However, the precise functional mechanism of how the KPI domain of APPs, initially described for its serine protease inhibitor properties, inhibits the metalloproteinase TACE [i.e., ADAM (a disintegrin and metalloprotease) protein family] remains undetermined but will be part of our future analyses.

In summary, the present study reveals a direct linkage between sustained but sublethal NMDAR activation and $\mathrm{A} \beta$ production in neurons. Although accumulation of $\mathrm{A} \beta$ after acute brain injuries may involve multiple mechanisms (Cotman et al., 1996), it can be suggested that even modest deregulation of the glutamatergic neurotransmission in the parenchyma surrounding the lesion may have an important impact on the probability to develop amyloid plaques. Thus, the pharmacological modulation of NMDAR function could represent a promising therapeutic intervention to reduce $\mathrm{A} \beta$ accumulation after acute brain injuries. A better understanding of the relationship between glutamatergic neurotransmission deregulation and the amyloidogenic pathway may improve our knowledge about $\mathrm{AD}$ itself and determine a better way to treat it.

\section{References}

Abe K, Tanzi RE, Kogure K (1991) Selective induction of Kunitz-type protease inhibitor domain-containing amyloid precursor protein mRNA after persistent focal ischemia in rat cerebral cortex. Neurosci Lett 125:172-174.

Arundine M, Tymianski M (2004) Molecular mechanisms of glutamatedependent neurodegeneration in ischemia and traumatic brain injury. Cell Mol Life Sci 61:657-668.

Barelli H, Lebeau A, Vizzavona J, Delaere P, Chevallier N, Drouot C, Marambaud P, Ancolio K, Buxbaum JD, Khorkova O, Heroux J, Sahasrabudhe S, Martinez J, Warter JM, Mohr M, Checler F (1997) Characterization of new polyclonal antibodies specific for 40 and 42 amino acid-long amyloid beta peptides: their use to examine the cell biology of presenilins and the immunohistochemistry of sporadic Alzheimer's disease and cerebral amyloid angiopathy cases. Mol Med 3:695-707.

Behrouz N, Defossez A, Delacourte A, Hublau P, Mazzuca M (1989) Alzheimer's disease: glycolytic pretreatment dramatically enhances immunolabeling of senile plaques and cerebrovascular amyloid substance. Lab Invest 61:576-583.

Blasko I, Beer R, Bigl M, Apelt J, Franz G, Rudzki D, Ransmayr G, Kampfl A, Schliebs R (2004) Experimental traumatic brain injury in rats stimulates the expression, production and activity of Alzheimer's disease betasecretase (BACE-1). J Neural Transm 111:523-536.

Bramlett HM, Dietrich WD (2004) Pathophysiology of cerebral ischemia and brain trauma: similarities and differences. J Cereb Blood Flow Metab 24:133-150.

Bussiere T, Friend PD, Sadeghi N, Wicinski B, Lin GI, Bouras C, Giannakopoulos P, Robakis NK, Morrison JH, Perl DP, Hof PR (2002) Stereologic assessment of the total cortical volume occupied by amyloid deposits and its relationship with cognitive status in aging and Alzheimer's disease. Neuroscience 112:75-91.

Buxbaum JD, Liu KN, Luo Y, Slack JL, Stocking KL, Peschon JJ, Johnson RS, Castner BJ, Cerretti DP, Black RA (1998) Evidence that tumor necrosis factor alpha converting enzyme is involved in regulated alpha-secretase cleavage of the Alzheimer amyloid protein precursor. J Biol Chem 273:27765-27767.

Choi DW (1988) Glutamate neurotoxicity and diseases of the nervous system. Neuron 1:623-634.

Choi DW (1995) Calcium: still center-stage in hypoxic-ischemic neuronal death. Trends Neurosci 18:58-60.

Cotman CW, Tenner AJ, Cummings BJ (1996) Beta-amyloid converts an acute phase injury response to chronic injury responses. Neurobiol Aging 17:723-731.

Fleminger S, Oliver DL, Lovestone S, Rabe-Hesketh S, Giora A (2003) Head injury as a risk factor for Alzheimer's disease: the evidence 10 years on; a partial replication. J Neurol Neurosurg Psychiatry 74:857-862.

Glenner GG, Wong CW (1984) Alzheimer's disease: initial report of the purification and characterization of a novel cerebrovascular amyloid protein. Biochem Biophys Res Commun 120:885-890.

Guo Z, Cupples LA, Kurz A, Auerbach SH, Volicer L, Chui H, Green RC, Sadovnick AD, Duara R, DeCarli C, Johnson K, Go RC, Growdon JH, Haines JL, Kukull WA, Farrer LA (2000) Head injury and the risk of AD in the MIRAGE study. Neurology 54:1316-1323.

Haass C, Schlossmacher MG, Hung AY, Vigo-Pelfrey C, Mellon A, Ostaszewski BL, Lieberburg I, Koo EH, Schenk D, Teplow DB, Selkoe DJ (1992) Amyloid beta-peptide is produced by cultured cells during normal metabolism. Nature 359:322-325.

Haass C, Hung AY, Schlossmacher MG, Teplow DB, Selkoe DJ (1993) Betaamyloid peptide and a $3-\mathrm{kDa}$ fragment are derived by distinct cellular mechanisms. J Biol Chem 268:3021-3024.

Hellal F, Pruneau D, Palmier B, Faye P, Croci N, Plotkine M, MarchandVerrecchia C (2003) Detrimental role of bradykinin B2 receptor in a murine model of diffuse brain injury. J Neurotrauma 20:841-851.

Heyman A, Wilkinson WE, Stafford JA, Helms MJ, Sigmon AH, Weinberg T (1984) Alzheimer's disease: a study of epidemiological aspects. Ann Neurol 15:335-341.

Ho L, Fukuchi K, Younkin SG (1996) The alternatively spliced Kunitz protease inhibitor domain alters amyloid beta protein precursor processing and amyloid beta protein production in cultured cells. J Biol Chem 271:30929-30934.

Hsiao K (1998) Transgenic mice expressing Alzheimer amyloid precursor proteins. Exp Gerontol 33:883-889. 
Hsiao K, Chapman P, Nilsen S, Eckman C, Harigaya Y, Younkin S, Yang F, Cole G (1996) Correlative memory deficits, Abeta elevation, and amyloid plaques in transgenic mice. Science 274:99-102.

Husi H, Grant SG (2001) Proteomics of the nervous system. Trends Neurosci 24:259-266.

Husi H, Ward MA, Choudhary JS, Blackstock WP, Grant SG (2000) Proteomic analysis of NMDA receptor-adhesion protein signaling complexes. Nat Neurosci 3:661-669.

Kim HS, Lee SH, Kim SS, Kim YK, Jeong SJ, Ma J, Han DH, Cho BK, Suh YH (1998) Post-ischemic changes in the expression of Alzheimer's APP isoforms in rat cerebral cortex. NeuroReport 9:533-537.

LeBlanc AC, Chen HY, Autilio-Gambetti L, Gambetti P (1991) Differential APP gene expression in rat cerebral cortex, meninges, and primary astroglial, microglial and neuronal cultures. FEBS Lett 292:171-178.

Lee JM, Zipfel GJ, Choi DW (1999) The changing landscape of ischaemic brain injury mechanisms. Nature 399:A7-14.

Linnik MD, Zobrist RH, Hatfield MD (1993) Evidence supporting a role for programmed cell death in focal cerebral ischemia in rats. Stroke 24:2002-2009.

MacDermott AB, Mayer ML, Westbrook GL, Smith SJ, Barker JL (1986) NMDA-receptor activation increases cytoplasmic calcium concentration in cultured spinal cord neurones. Nature 321:519-522.

MacManus JP, Buchan AM, Hill IE, Rasquinha I, Preston E (1993) Global ischemia can cause DNA fragmentation indicative of apoptosis in rat brain. Neurosci Lett 164:89-92.

Masters CL, Simms G, Weinman NA, Multhaup G, McDonald BL, Beyreuther K (1985) Amyloid plaque core protein in Alzheimer disease and Down syndrome. Proc Natl Acad Sci USA 82:4245-4249.

Mattson MP, Cheng B, Culwell AR, Esch FS, Lieberburg I, Rydel RE (1993) Evidence for excitoprotective and intraneuronal calcium-regulating roles for secreted forms of the beta-amyloid precursor protein. Neuron 10:243-254.

Moir RD, Lynch T, Bush AI, Whyte S, Henry A, Portbury S, Multhaup G, Small DH, Tanzi RE, Beyreuther K, Masters CL (1998) Relative increase in Alzheimer's disease of soluble forms of cerebral Abeta amyloid protein precursor containing the Kunitz protease inhibitory domain. J Biol Chem 273:5013-5019.

Mortimer JA, van Duijn CM, Chandra V, Fratiglioni L, Graves AB, Heyman A, Jorm AF, Kokmen E, Kondo K, Rocca WA (1991) Head trauma as a risk factor for Alzheimer's disease: a collaborative re-analysis of casecontrol studies. EURODEM Risk Factors Research Group. Int J Epidemiol 20 [Suppl 2]:S28-S35.

Nagy Z, Esiri MM, Jobst KA, Morris JH, King EM, McDonald B, Joachim C, Litchfield S, Barnetson L, Smith AD (1997) The effects of additional pathology on the cognitive deficit in Alzheimer disease. J Neuropathol Exp Neurol 56:165-170.

Plassman BL, Havlik RJ, Steffens DC, Helms MJ, Newman TN, Drosdick D, Phillips C, Gau BA, Welsh-Bohmer KA, Burke JR, Guralnik JM, Breitner JC (2000) Documented head injury in early adulthood and risk of Alzheimer's disease and other dementias. Neurology 55:1158-1166.

Popa-Wagner A, Schroder E, Walker LC, Kessler C (1998) Beta-amyloid precursor protein and ss-amyloid peptide immunoreactivity in the rat brain after middle cerebral artery occlusion: effect of age. Stroke 29:2196-2202.

Refolo LM, Salton SR, Anderson JP, Mehta P, Robakis NK (1989) Nerve and epidermal growth factors induce the release of the Alzheimer amyloid precursor from PC 12 cell cultures. Biochem Biophys Res Commun 164:664-670.

Roberts GW, Gentleman SM, Lynch A, Graham DI (1991) Beta A4 amyloid protein deposition in brain after head trauma. Lancet 338:1422-1423.

Roberts GW, Gentleman SM, Lynch A, Murray L, Landon M, Graham DI
(1994) Beta amyloid protein deposition in the brain after severe head injury: implications for the pathogenesis of Alzheimer's disease. J Neurol Neurosurg Psychiatry 57:419-425.

Rose K, Goldberg MP, Choi DW (1993) Cytotoxicity in murine neocortical cell culture. In: In vitro biological methods. Methods in toxicology (Tyson CA, Frazier JM, eds), pp 46-60. San Diego: Academic.

Roses AD, Saunders A (1995) Head injury, amyloid beta and Alzheimer's disease. Nat Med 1:603-604.

Saido TC, Yokota M, Maruyama K, Yamao-Harigaya W, Tani E, Ihara Y, Kawashima S (1994) Spatial resolution of the primary betaamyloidogenic process induced in postischemic hippocampus. J Biol Chem 269:15253-15257.

Schlondorff J, Becherer JD, Blobel CP (2000) Intracellular maturation and localization of the tumour necrosis factor alpha convertase (TACE). Biochem J 347:131-138.

Schulz JB, Weller M, Moskowitz MA (1999) Caspases as treatment targets in stroke and neurodegenerative diseases. Ann Neurol 45:421-429.

Selkoe DJ (2001) Alzheimer's disease: genes, proteins, and therapy. Physiol Rev 81:741-766.

Sergeant N, David JP, Champain D, Ghestem A, Wattez A, Delacourte A (2002) Progressive decrease of amyloid precursor protein carboxy terminal fragments (APP-CTFs), associated with tau pathology stages, in Alzheimer's disease. J Neurochem 81:663-672.

Skovronsky DM, Moore DB, Milla ME, Doms RW, Lee VM (2000) Protein kinase C-dependent alpha-secretase competes with beta-secretase for cleavage of amyloid-beta precursor protein in the trans-golgi network. J Biol Chem 275:2568-2575.

Smith DH, Nakamura M, McIntosh TK, Wang J, Rodriguez A, Chen XH, Raghupathi R, Saatman KE, Clemens J, Schmidt ML, Lee VM, Trojanowski JQ (1998) Brain trauma induces massive hippocampal neuron death linked to a surge in beta-amyloid levels in mice overexpressing mutant amyloid precursor protein. Am J Pathol 153:1005-1010.

Smith DH, Chen XH, Iwata A, Graham DI (2003) Amyloid beta accumulation in axons after traumatic brain injury in humans. J Neurosurg 98:1072-1077.

Snowdon DA, Greiner LH, Mortimer JA, Riley KP, Greiner PA, Markesbery WR (1997) Brain infarction and the clinical expression of Alzheimer disease. The nun study. JAMA 277:813-817.

Sturchler-Pierrat C, Abramowski D, Duke M, Wiederhold KH, Mistl C, Rothacher S, Ledermann B, Burki K, Frey P, Paganetti PA, Waridel C, Calhoun ME, Jucker M, Probst A, Staufenbiel M, Sommer B (1997) Two amyloid precursor protein transgenic mouse models with Alzheimer disease-like pathology. Proc Natl Acad Sci USA 94:13287-13292.

Tao X, Finkbeiner S, Arnold DB, Shaywitz AJ, Greenberg ME (1998) $\mathrm{Ca}^{2+}$ influx regulates BDNF transcription by a CREB family transcription factor-dependent mechanism. Neuron 20:709-726.

Uryu K, Laurer H, McIntosh T, Pratico D, Martinez D, Leight S, Lee VM, Trojanowski JQ (2002) Repetitive mild brain trauma accelerates Abeta deposition, lipid peroxidation, and cognitive impairment in a transgenic mouse model of Alzheimer amyloidosis. J Neurosci 22:446-454.

West AE, Chen WG, Dalva MB, Dolmetsch RE, Kornhauser JM, Shaywitz AJ, Takasu MA, Tao X, Greenberg ME (2001) Calcium regulation of neuronal gene expression. Proc Natl Acad Sci USA 98:11024-11031.

Willoughby DA, Rozovsky I, Lo AC, Finch CE (1995) Beta-amyloid precursor protein (APP) and APP-RNA are rapidly affected by glutamate in cultured neurons: selective increase of mRNAs encoding a Kunitz protease inhibitor domain. J Mol Neurosci 6:257-276.

Xie J, Black DL (2001) A CaMK IV responsive RNA element mediates depolarization-induced alternative splicing of ion channels. Nature 410: 936-939. 